\title{
Effect of Infection with Phage Lambda on the Synthesis of Protein, RNA and DNA in Escherichia coli
}

\author{
By W. M. WAITES and B. A. FRY \\ Department of Microbiology, University of Sheffield
}

(Received 29 July 1963)

\begin{abstract}
SUMMARY
Delay in deoxyribonucleic acid (DNA) synthesis after use of ultraviolet radiation to induce Escherichia coli lysogenic for phage $\lambda$ was due to the irradiation procedure; the same delay was found in non-lysogenic bacteria exposed to the same dose of radiation. After infection with phage $\lambda_{c}$ or $\lambda_{v}$ in $0.02 \mathrm{M}-\mathrm{MgSO}_{4}$, DNA synthesis began without delay when complete medium was added. During vegetative development of phage in induced bacteria, 81-89\% of the DNA synthesized was accounted for in the phage progeny, indicating that host DNA synthesis is much diminished and may be completely inhibited. Mature phage particles arose soon after the appearance of serum blocking power (SBP) and endolysin activity. Induced bacteria synthesized up to 15 times more SBP than was incorporated into complete phage particles: the excess SBP was not sedimented at $40,000 \mathrm{~g}$ (unlike phage particles), but about half was sedimented at $90,000 \mathrm{~g}$, the rest remaining in the supernatant fluid. Whilst protein and RNA synthesis in infected or induced bacteria was initially similar to that in the control, there was a marked decrease of synthesis in the second half of the latent period.
\end{abstract}

\section{INTRODUCTION}

The extent to which host-cell metabolism is affected by the vegetative development of bacteriophage has been studied almost exclusively in Escherichia coli infected with the $T$ series of coliphages. Thus in bacteria infected with phage $T_{2}$ or $\mathbf{T}_{4}$, there are profound effects on the net synthesis of ribo- and deoxyribo-nucleic acids (Cohen, 1948), and early in the latent period several new enzymes must be produced before the synthesis of specific phage components can take place (see Flaks, Lichtenstein \& Cohen, 1959; Bessman, 1960). Analogous studies of the events during the latent period in cells infected with temperate bacteriophage (i.e. bacteriophage which can exist in the lysogenic state) have until recently received comparatively little attention and most of the data concerned Bacillus megaterium (Siminovitch \& Rapkine, 1952). When $\boldsymbol{B}$. megaterium lysogenic for phage 1 was induced by ultraviolet (u.v.) radiation, there was little change in the rate of synthesis of ribonucleic acid (RNA) and protein. On the other hand, no net synthesis of deoxyribonucleic acid (DNA) was detected during the first part of the latent period. Since after infection of $E$. coli with phage $\mathbf{T}_{2}$ there is also a lag period before DNA synthesis is resumed (Cohen, 1948), it was of interest to know whether the lag observed in the induced organisms was a direct effect of the onset of phage development, or only a secondary and indirect effect brought about by the irradiation 
procedure. The exposure of the non-lysogenic parent $B$. megaterium to the same dose of u.v. radiation was in fact found to produce no lag in the synthesis of DNA (Siminovitch \& Rapkine, 1952). However, with $E$. coli it has long been known that exposure to u.v. radiation causes inhibition of DNA synthesis, and the period of this inhibition is directly related to the dose of radiation (Kelner, 1953). In the present work, a study has been made of the effect of vegetative phage development on host-cell metabolism first in $E$. coli lysogenic for wild-type phage $\lambda$ after induction by u.v. radiation, and secondly in $E$. coli after infection with phage mutants $\lambda_{c}$ and $\lambda_{v}$. The latter are mutants of phage $\lambda$ which have lost the ability to lysogenize $E$. coli; phage $\lambda_{c}$ can infect and develop in bacteria which are not lysogenic for phage $\lambda$, whilst phage $\lambda_{v}$ (virulent inducer mutant) will infect and develop in $E$. coli, whether or not the bacteria are lysogenic for phage $\lambda$ (Jacob \& Wollman, 1954). Recently Séchaud (1960) showed that when starved $E$. coli organisms were infected with phage $\lambda_{c}$ in the presence of $\mathrm{MgSO}_{4}$ and then transferred to complete medium, there was a delay of about $8 \mathrm{~min}$. before net DNA synthesis was resumed. Most, if not all, of this period appeared to be required for events concerned with the injection of the phage DNA into the host cell.

\section{METHODS}

Organisms. Escherichia coli $\mathrm{K} 12$ strains $\mathrm{k} 112$ and $\mathrm{c} 600$, and the phages $\lambda_{22}$ (wildtype) and the two mutants $\lambda_{g c}$ and $\lambda_{g v}$ (large plaque-forming mutants) have been described by Jacob \& Wollman (1954, 1956b) and Fry (1959).

Growth media and assay methods. In general the media and plating procedures were based on those of Adams (1950). Peptone broth (PB) contained (g./l.) 10, Oxoid peptone; 1, Lab. Lemco; at $\mathrm{pH}$ 7. Tryptone broth (TB) contained (g./l.) 20, Oxoid tryptone; at $\mathrm{pH}$ 7. Phage stocks were stored and diluted in medium PB. For plating, medium PB was supplemented with $1 \% \mathrm{NaCl}$ and agar (Parke-Davis) as required ( $1 \%$ for the bottom layer of plates for phage and viable counts; $0.7 \%$ for the small tubes in which samples were mixed before plating). Escherichia coli strain $\mathbf{c} 600$ was used as indicator organism in the phage assays.

Preparation of phage stocks. Stocks of phage $\lambda_{22}$, prepared by the induction of Escherichia coli $\left(\lambda_{22}\right)$ and concentrated by centrifugation (see Fry, 1959), were stable for several months at $4^{\circ}$ and contained about $1 \times 10^{12}$ active particles $/ \mathrm{ml}$. Small stocks of phage $\lambda_{g v}$ and $\lambda_{g c}$ were prepared from plates by the confluent lysis technique and these were used to infect cultures (1 1.) of $E$. coli $\mathrm{c} 600$ in the log phase of growth $\left(5 \times 10^{8}\right.$ bacteria/ml. $)$ at a multiplicity of $5 \lambda$ phage/cell. Cultures were incubated until lysis was complete, and then any whole bacteria and cell debris removed. The phage particles were collected by centrifugation (as for phage $\lambda_{22}$ ) and the pellet suspended in a small volume of medium PB.

Ultraviolet irradiation. An Hanovia Chromatolite low-pressure Hg lamp (Hanovia Ltd., Slough, England) without the filter was placed $75 \mathrm{~cm}$. from the sample $(100 \mathrm{ml}$.), which was rocked gently to and fro in an enamel dish $(32 \times 28 \mathrm{~cm}$.). Irradiations were done in a dark room and in these conditions a dose of 60 sec. was just sufficient for the optimal induction (i.e. $90 \%$ or more) of Escherichia coli $\mathrm{x} 112$ $\left(\lambda_{22}\right)$ : this dose allowed $30 \%$ survival of non-lysogenic coli $\mathrm{k} 112$ (measured as ability to form colonies) and $45 \%$ survival of phage $\lambda_{22}$ (measured as ability to form plaques). 
Preparation of samples and the determination of protein, $R N A$ and $D N A$. Samples of cultures were taken at the required times and $1 \mathrm{ml}$. used for the determination of growth (in terms of turbidity), whilst $6 \mathrm{ml}$. were rapidly mixed with $0 \cdot 6 \mathrm{ml}$. $\mathbf{5 0} \%$ trichloroacetic acid (TCA). After standing overnight at $4^{\circ}$ the precipitates were collected by centrifugation and washed once with $5 \mathrm{ml} .5 \%$ TCA. Each precipitate was then suspended in $2 \mathrm{ml} .5 \%$ TCA and heated at $90^{\circ}$ for $30 \mathrm{~min}$. in a water bath; double aluminium foil caps on the tubes prevented evaporation. After centrifugation the supernatant fluids were carefully removed and kept for the assay of RNA and DNA. Residues were dissolved in $\mathrm{N}-\mathrm{NaOH}$ and $\mathbf{0 . 5} \mathrm{ml}$. samples were used for the assay of protein by the method of Lowry, Rosebrough, Farr \& Randall (1951). Each sample received $5 \mathrm{ml}$. of the reagent prepared from $50 \mathrm{ml} .2 \% \mathrm{Na}_{2} \mathrm{CO}_{3}$ and $1 \mathrm{ml} .0 .5 \% \mathrm{CuSO}_{4}$ in $1 \% \mathrm{NaK}$ tartrate, followed after $10 \mathrm{~min}$. by $0.5 \mathrm{ml}$. Folin-Ciocalteu reagent in $\mathrm{N}-\mathrm{HCl}$ (British Drug Houses Ltd). After standing for $1 \mathrm{hr}$ at $37^{\circ}$, the absorption of the blue colour was determined at $500 \mathrm{~m} \mu$ (blue photo cell). A standard protein solution was prepared from bovine plasma albumin fraction V (Armour Pharmaceutical Co. Ltd., Eastbourne) in N-NaOH. For the determination of RNA, a suitable sample of the hot TCA extract in a total volume of $1.5 \mathrm{ml} .5 \% \mathrm{TCA}$ was mixed with $1.5 \mathrm{ml}$. of $0.5 \% \mathrm{FeCl}_{3}$ in concentrated $\mathrm{HCl}$ and $0.15 \mathrm{ml} .10 \%$ orcinol in absolute ethanol, and then heated at $100^{\circ}$ for $30 \mathrm{~min}$. (Schneider, 1945). After cooling, the absorption of the green colour was read at $660 \mathrm{~m} \mu$ (red photocell). D-Ribose (L. Light, Colnbrook, Bucks.) served as the standard, and results are expressed in terms of $\mu \mathrm{g}$. apparent ribose. DNA was determined by the method of Burton (1956). Samples (1 ml.) of the hot TCA extract were each mixed with $0.2 \mathrm{ml}$. of $3 \mathrm{~N}-\mathrm{HClO}_{4}$ and $1.2 \mathrm{ml}$. of Burton's acetaldehyde-Dische reagent. After overnight incubation at $37^{\circ}$, the blue colour was read at $600 \mathrm{~m} \mu$ (blue photocell). 2-Deoxy-D-ribose (L. Light, Colnbrook, Bucks.) served as the standard and results are expressed in terms of $\mu \mathrm{g}$. apparent deoxyribose. (The word 'apparent' is used because only the ribose and deoxyribose bound to purine nucleotides reacts in these procedures).

Determination of DNA content of phage $\lambda_{22}$. The phage particles were collected as a pellet by centrifugation for $1 \mathrm{hr}$ at $40,000 \mathrm{~g}$, the supernatant fluid removed and the pellet extracted overnight with $2 \%$ tryptone solution. Insoluble material was removed ( $8000 \mathrm{~g}$ for $15 \mathrm{~min}$.) and then the phage suspension centrifuged at $105,000 \mathrm{~g}$ for $1 \mathrm{hr}$. After removing the supernatant fluid as completely as possible, the pellets were extracted overnight with $0.05 \mathrm{M}$ phosphate buffer $(\mathrm{pH} 7)$ containing $0.01 \mathrm{M}$ $\mathrm{MgSO}_{4}$ and insoluble material removed (8000 $\mathrm{g}$ for $15 \mathrm{~min}$.). The supernatant fluid was assayed for phage particles and 1 and $2 \mathrm{ml}$. samples used for the determination of DNA. The purified phage preparation contained $3 \cdot 8 \times 10^{11}$ particles $/ \mathrm{ml}$. (from mean of four plates; standard deviation $\pm 0 \cdot 2 \times 10^{11}$ ) and $8 \cdot 14 \mu \mathrm{g}$. apparent deoxyribose/ml. (from mean of 3 determinations; standard deviation \pm 0.41 ), giving $2 \cdot 14 \times 10^{-11} \mu \mathrm{g}$. apparent deoxyribose/particle of phage $\lambda_{22}$.

Assay of serum blocking power (SBP). The methods used were based on those of DeMars (1955) and Jacob \& Wollman (1956). Samples of the cultures were stored in ice until they were placed in the ultrasonic generator $(2 \mathrm{~min}$. exposure in a $1 \mathrm{~kW}$. Mullard generator). The disintegrated suspensions were stored at $0^{\circ}$ until required (usually overnight). Samples $(0.2 \mathrm{ml}$.) containing the SBP material to be assayed were mixed with $0.8 \mathrm{ml}$. of $1.25 \times 10^{-4}$ dilution of phage antiserum (neutralization 
value, $\mathrm{k},=200)$ and incubated for $6 \mathrm{hr}$ at $37^{\circ}$. The test phage $\left(\lambda_{g v}\right)$ was then added $\left(0.2 \mathrm{ml}\right.$. containing about $2 \times 10^{7}$ particles $)$ and the mixture incubated for a further $3 \mathrm{hr}$. before plating appropriate dilutions with the indicator organism, strain к $112\left(\lambda_{22}\right)$. Standard curves were prepared by using stock phage suspensions.

Assay of endolysin. The method used was based on that of Jacob \& Fuerst (1958). The lytic activity of the suspensions of bacteria disrupted by ultrasonic treatment was tested against bacterial suspensions prepared as follows. Cells of Escherichia coli $\mathrm{k} 112$ were harvested from growing cultures $\left(5 \times 10^{8}\right.$ organisms $/ \mathrm{ml}$.), washed once with distilled water and resuspended in $0 \cdot 1 \mathrm{~m}$ ethylenediaminetetra-acetate (EDTA) at $\mathrm{pH} 8 \cdot 3$. After $5 \mathrm{~min}$. at $37^{\circ}$, the bacteria were collected by centrifugation, washed and suspended in distilled water. Such bacterial suspensions (optical density, $E,=1 \cdot 0$ ) could be kept at $0^{\circ}$ for $48 \mathrm{hr}$. Endolysin activity was determined by adding the sample (1.5 ml.) to $1.5 \mathrm{ml}$. of the washed bacterial suspension and the optical density read at intervals at $610 \mathrm{~m} \mu$ (blue photocell). When endolysin is present, the optical density at first decreases linearly for a period, and then less rapidly to a plateau value, after which there is little or no further change with time. The rate of change in optical density ( $\Delta E / \mathrm{min}$.) over the initial linear portion of the graph was taken as a measure of the amount of endolysin in the sample.

Determination of viable counts. The sample was diluted in $0.9 \% \mathrm{NaCl}$ solution and then plated by the soft agar layer technique on to PB agar plates.

Measurement of turbidity. Measurements of optical density, $E$, were made at $610 \mathrm{~m} \mu$ (blue photocell).

Spectrophotometry. All measurements were made in a Unicam spectrophotometer Model SP 600 with $1 \mathrm{~cm}$. glass cells.

Experimental procedure. Large-scale cultures were grown in conical flasks (150 ml. medium TB/1 l. flask) shaken in a water bath at $37^{\circ}$. Cultures were normally harvested when they reached $5 \times 10^{8}$ bacteria $/ \mathrm{ml}$. When the bacteria were to be u.v.-irradiated, they were collected by centrifugation and resuspended at an optical density of about 0.6 in $0.9 \% \mathrm{NaCl}$ solution containing 0.1 vol. of medium $\mathrm{PB}$ or TB (i.e. about $6 \times 10^{8}$ bacteria $/ \mathrm{ml}$.). The suspension was divided into two parts; one was irradiated and the other kept as the control. Within about 2 min. of irradiation, $100 \mathrm{ml}$. of each suspension were placed in a 1 l. flask, $20 \mathrm{ml} .10 \%$ tryptone at $65^{\circ}$ added (to bring the culture to $37^{\circ}$ quickly), and then shaken in a water bath at $37^{\circ}$.

For infection with phage $\lambda_{g c}$ or $\lambda_{g v}$ in the growth medium, cultures were grown to $5 \times 10^{8}$ bacteria/ml., $\mathrm{MgSO}_{4}$ added to a final concentration of $0.02 \mathrm{M}$, and then infected with a high-titre phage stock (multiplicity 10 particles/bacterium). For infection in the absence of growth medium, the culture was centrifuged and resuspended in $0.02 \mathrm{M}-\mathrm{MgSO}_{4}$; a small volume of high-titre phage suspension was then added, and after $15 \mathrm{~min}$. at $37^{\circ}$ the bacteria were collected by centrifugation and resuspended in warm $2 \%$ tryptone medium.

All percentages of solutes are $\mathrm{w} / \mathrm{v}$ and all incubations were done at $37^{\circ}$ unless otherwise stated. 


\section{RESULTS}

\section{Effect of induction of Escherichia coli lysogenic for wild-type phage $\lambda_{22}$}

When the induced bacteria were incubated in complete medium, the turbidity of the culture increased for about $70 \mathrm{~min}$. (phase of residual growth) and then lysis began (Fig. 1). Although for the first few minutes the rates of protein and RNA synthesis were the same in the induced and control (unirradiated) bacteria, the rates in the induced culture eventually became slower than in the control culture (Fig. 2).

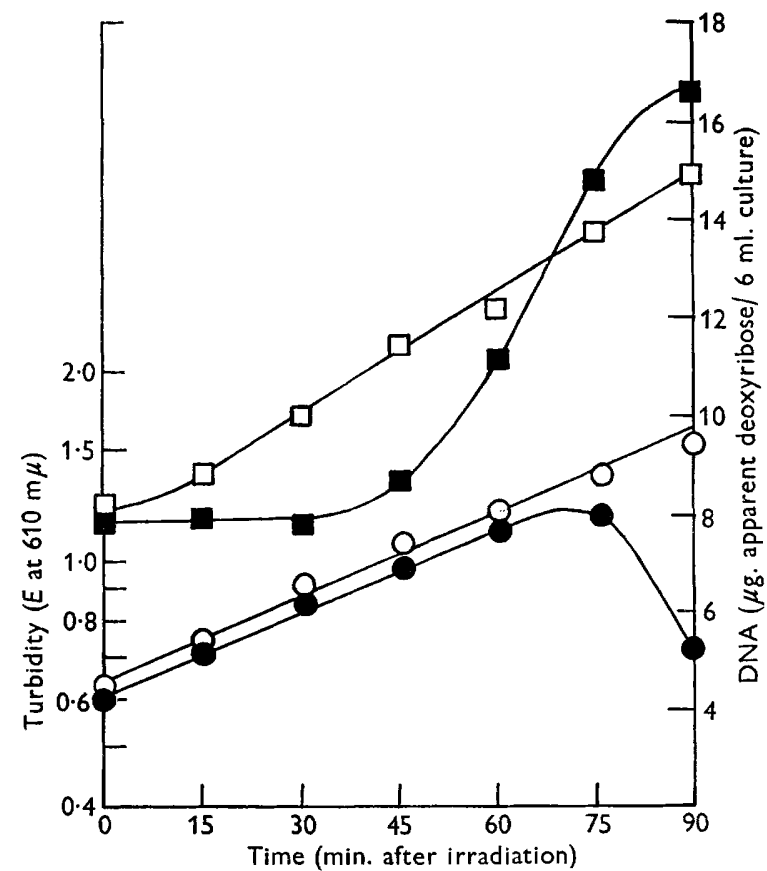

Fig. 1. Growth of Escherichia coli $\times 112(\lambda)$ and the synthesis of DNA after the induction of phage development by ultraviolet radiation. Experimental procedure described in Methods (p. 416). Samples were taken for the determination of turbidity $(O, O)$ and DNA $(\square, \square)$ : closed symbols for irradiated culture and open symbols for control (unirradiated). Initially $5.6 \times 10^{8}$ bacteria $/ \mathrm{ml}$. and $96 \%$ were induced.

In the induced bacteria, the net synthesis of DNA was completely inhibited during the first $30 \mathrm{~min}$. of the latent period (Figs. 1, 2). After this lag, synthesis was resumed and eventually became faster than in the unirradiated bacteria (Fig. 1). Similar experiments were done with the non-lysogenic parent strain. By comparing Figs. 2 and 3 it can be seen that the changes in DNA, RNA and protein synthesis which occurred in the induced bacteria were similar to the changes produced in the non-lysogenic bacteria by the same dose of radiation as used in the induction experiments. It was therefore concluded that the lag in DNA synthesis and the falling off in the synthesis of RNA and protein observed in the induced organisms were due to the effects of the irradiation on the general metabolic processes of the bacteria and were not a reflexion of events concerned with phage development. 


\section{Comparison of amount of DNA synthesized with DNA present in phage progeny}

An attempt was made to determine how much of the DNA made after the induction of Escherichia coli $\mathrm{k} 112(\lambda)$ was phage DNA. The base composition of DNA from phage and host are the same (Lwoff, 1953; Kaiser \& Hogness, 1960), so there is no direct way of following the synthesis of phage DNA as distinct from host DNA. However, the phage yield can be determined, and, when the DNA content of a phage $\lambda$

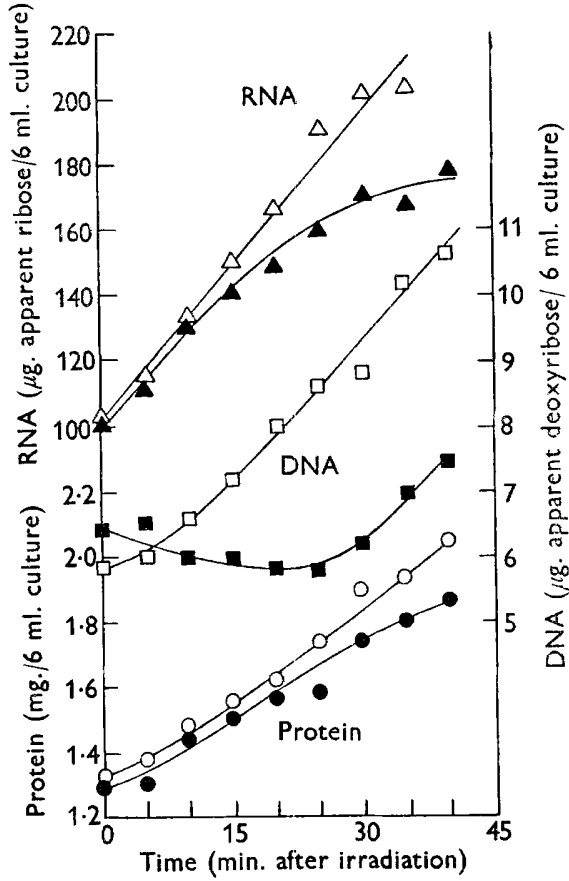

Fig. 2

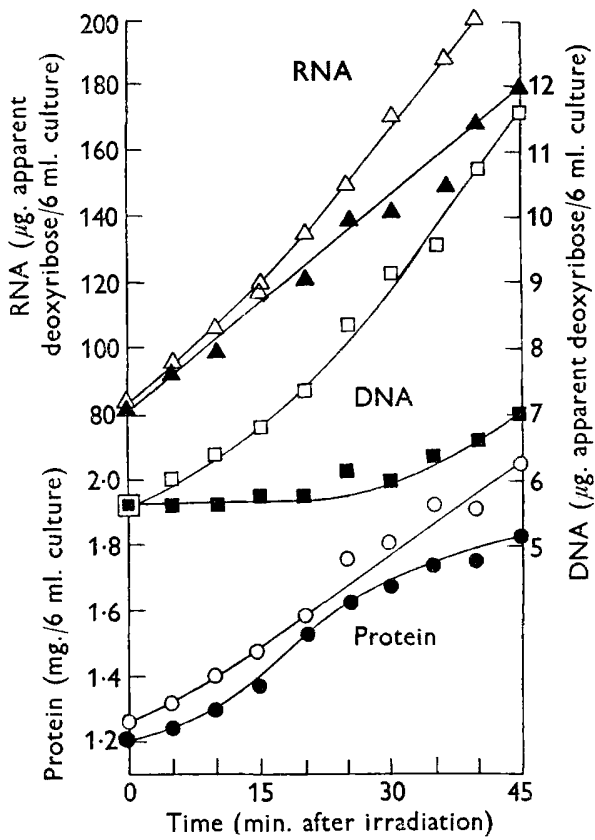

Fig. 3

Fig. 2. The synthesis of protein $(O, \odot), \operatorname{RNA}(\triangle, \Delta)$ and DNA $(\square, \square)$ in Escherichia coli $\mathrm{K} 112(\lambda)$ during the first half of the latent period after induction of phage development by ultraviolet radiation (closed symbols for irradiated culture and open symbols for control culture). Experimental procedures as for Fig. 1. Initially $3 \cdot 8 \times 10^{8} \mathrm{bacteria} / \mathrm{ml}$. and $89 \%$ were induced.

Fig. 3. The synthesis of protein $(O, \odot), \operatorname{RNA}(\triangle, \Delta)$ and DNA $(\square, \square)$ in non-lysogenic Escherichia coli $\mathrm{K} 112$ after exposure to ultraviolet radiation (closed symbols for irradiated culture and open symbols for control culture). Experimental procedure and dose of ultraviolet radiation as for Fig. 2. Initially $3 \cdot 9 \times 10^{8}$ bacteria $/ \mathrm{ml}$. and $77 \%$ were killed.

particle is known (see Methods, p. 415), the amount of DNA present in the phage progeny can be compared with the total amount of DNA synthesized in the culture. Experiments with induced bacteria (Table 1) showed that the DNA estimated to be present in the phage yield accounted for an appreciable part (between 81 and $89 \%$ ) of the DNA synthesized after irradiation. Hence the synthesis of host DNA was at least very much decreased during the vegetative development of phage $\lambda$; perhaps no synthesis took place at all and the excess DNA was phage DNA which had not 
been incorporated into complete phage particles (see similar experiments with phage $\mathrm{T}_{2}$ by Hershey, 1953, and Hershey \& Burgi, 1956). One of the main difficulties in this type of experiment is to measure the phage yield. If this is done by assay of the bulk culture when lysis is complete then some of the phage particles will have been lost by adsorption to cell debris and unlysed bacteria and thus the estimate of the phage yield will be inaccurate. If to avoid this the practice of Ellis \& Delbruck (1939) is followed and a sample of the culture is diluted several thousand times before lysis begins, the assumption has to be made that the phage yield/bacterium in the diluted culture is the same as in the bulk culture from which samples for the estimation of DNA are obtained. The figures in Table 1, Expt. 1, show how great the difference was between phage yield as determined by direct assay of the bulk culture and the value obtained from the diluted culture.

Table 1. Synthesis of $D N A$ and the production of phage particles after the induction of Escherichia coli $\mathrm{k} 112(\lambda)$ by ultraviolet radiation

Bacteria were harvested from cultures in the $\log$ phase of growth, resuspended, irradiated and, after the addition of warm medium, incubated at $37^{\circ}$ (details as in Methods, p. 416). After $40 \mathrm{~min}$., a sample was diluted $6 \times 10^{5}$ times in tryptone broth (at $37^{\circ}$ ) and also incubated with shaking. A sample of the diluted culture was immediately plated to determine the number of induced bacteria. After $120 \mathrm{~min}$. a sample of the diluted culture was incubated for a further $30 \mathrm{~min}$. in TB+0.02 $\mathrm{M}-\mathrm{KCN}$ (Doerman, 1952; Weigle \& Delbruck, 1951), and then assayed for phage particles. Figure in parentheses shows phage particles found in sample of bulk culture taken at $120 \mathrm{~min}$. and incubated in $\mathrm{TB}+0.02 \mathrm{M}-\mathrm{KCN}$ for $30 \mathrm{~min}$. The phage particles present at the time of irradiation were determined after incubating a sample of the unirradiated bacteria in broth $+0.02 \mathrm{M}$ $\mathrm{KCN}+\mathrm{a}$ drop of chloroform for $30 \mathrm{~min}$. In Expt. 1, at time $0 \mathrm{~min} .5 \cdot 9 \times 10^{8}$ bacteria $/ \mathrm{ml}$., and $93 \%$ were induced: in Expt. 2, 8.6 $\times 10^{8}$ bacteria $/ \mathrm{ml}$. and 93\% were induced: in Expt. $3,6.7 \times 10^{8}$ bacteria $/ \mathrm{ml}$., and $90 \%$ were induced. All results are expressed per $6 \mathrm{ml}$. of culture. DNA content of phage $2 \cdot 14 \times 10^{-11} \mu \mathrm{g}$. apparent deoxyribose/particle (Methods, p. 415).

\begin{tabular}{|c|c|c|c|c|c|c|}
\hline \multicolumn{2}{|c|}{$\begin{array}{c}\text { Total apparent } \\
\text { deoxyribose } \\
\text { ( } \mu \mathrm{g} . / 6 \mathrm{ml} \text {. culture }) \\
\text { At }\end{array}$} & \multirow{2}{*}{$\begin{array}{c}\text { DNA } \\
\text { synthesized } \\
\text { ( } \mu \mathrm{g} . \text { apparent } \\
\text { deoxyribose) } \\
(\mathrm{B}-\mathrm{A})\end{array}$} & \multicolumn{2}{|c|}{$\begin{array}{c}\text { Phage } \\
\text { (particles } / 6 \mathrm{ml} .) \\
\text { At }\end{array}$} & \multirow{2}{*}{$\begin{array}{c}\text { Apparent } \\
\text { deoxyribose } \\
\text { in phage } \\
(\mu \mathrm{g} .) \\
(\mathrm{C})\end{array}$} & \multirow{2}{*}{$\begin{array}{c}\% \\
\text { of DNA } \\
\text { synthesized } \\
\text { in phage } \\
\frac{(\mathrm{C} \times 100)}{(\mathbf{B}-\mathbf{A})}\end{array}$} \\
\hline $\begin{array}{c}0 \text { min. } \\
\text { (A) }\end{array}$ & $\begin{array}{l}120 \mathrm{~min} \text {. } \\
\text { (B) }\end{array}$ & & $0 \mathrm{~min}$. & $120 \mathrm{~min}$. & & \\
\hline $8 \cdot 26$ & $28 \cdot 58$ & $20 \cdot 32$ & $5 \cdot 4 \times 11$ & $\begin{array}{c}7.7 \times 10^{11} \\
\left(2.5 \times 10^{11}\right)\end{array}$ & $16 \cdot 47$ & 81 \\
\hline $11 \cdot 52$ & $42 \cdot 40$ & $30 \cdot 88$ & $3 \cdot 8 \times 10$ & ${ }^{6} 1.2 \times 10^{12}$ & $25 \cdot 62$ & 83 \\
\hline $9 \cdot 54$ & $24 \cdot 50$ & 14.96 & - & $6.2 \times 10^{11}$ & $13 \cdot 26$ & 89 \\
\hline
\end{tabular}

Effect of infection of Escherichia coli ${ }_{k} 112$ with phage $\lambda_{g c}$

Infection with phage $\lambda_{g c}$ or $\lambda_{g v}$ can be done in a medium which does not support growth, e.g. in 0.02 $\mathrm{M}-\mathrm{MgSO}_{4}$ alone, or in the growth medium itself supplemented with $0.02 \mathrm{M}-\mathrm{MgSO}_{4}$. The former conditions enable the majority (90\%) of the bacteria to be infected, and, when they are subsequently transferred to the growth medium, phage development will begin in all the bacteria at the same time. This procedure is preferred since, when organisms are infected in the growth medium, unless infection of the population as a whole is very rapid the events which occur in the infected bacteria will tend to be blurred by those in non-infected bacteria. After exposure to phage $\lambda_{g c}$ in $0.02 \mathrm{M}-\mathrm{MgSO}_{4}, 95 \%$ of the bacteria were infected, and there 
was little residual growth when they were placed in broth (though the non-infected bacteria grew without lag). One reflexion of this was the small amount of protein synthesis (Fig. 4a). The synthesis of DNA occurred without delay in both infected and non-infected bacteria, but the rate of synthesis in infected bacteria was somewhat more rapid during the latter part of the latent period (Fig. $4 b$ ). In the experiment reported, no net synthesis of RNA was detected, although the amount of RNA in the control bacteria increased steadily (Fig. 4b). Lysis of the infected bacteria began at about $\mathbf{3 5} \mathrm{min}$.
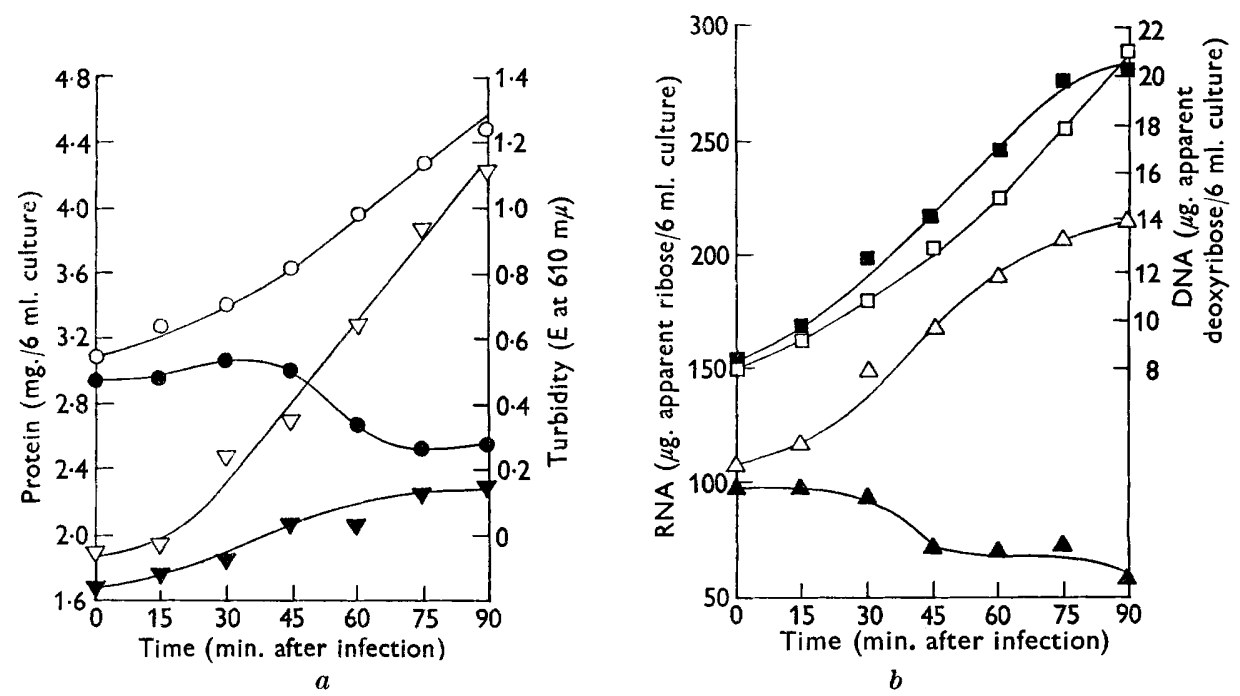

Fig. 4. Growth of Escherichia coli $\mathrm{k} 112$ and the synthesis of protein, RNA and DNA after infection with phage $\lambda_{g c}$ in the presence of $0.02 \mathrm{M}-\mathrm{MgSO}_{4}$ alone. A log-phase culture was harvested, suspended in $0.02 \mathrm{M}-\mathrm{MgSO}_{4}\left(5.7 \times 10^{8}\right.$ bacteria $/ \mathrm{ml}$.) and divided into two parts. One part received a small volume of phage $\lambda_{g c}\left(8.5 \times 10^{9}\right.$ particles $/ \mathrm{ml}$. $)$ in $0.02 \mathrm{M}-$ $\mathrm{MgSO}_{4}$ : the other part was mixed with $\mathrm{MgSO}_{4}$ alone. After $15 \mathrm{~min}$. at $37^{\circ}$, the cells were harvested and resuspended in warm TB medium, and samples taken at intervals for the determination of $(a)$ turbidity $(O, \ominus)$ and protein $(\nabla, \nabla)$ and $(b) \operatorname{RNA}(\triangle, \Delta)$ and DNA $(\square, \square)$. Closed symbols for infected culture and open symbols for control culture.

When bacteria in the log phase of growth were infected in the growth medium with phage $\lambda_{g c}$ there was an appreciable amount of residual growth before lysis began after about $30 \mathrm{~min}$ (Fig. 5a). Total protein synthesis in the infected bacteria was less than in the control bacteria (Fig. 5a), and again there was no lag in the synthesis of DNA, the rate of synthesis of which during the latent period was greater than in the uninfected organisms (Fig. $5 b$ ). The synthesis of RNA in the infected bacteria was much reduced (Fig. $5 b$ ).

\section{Effect of infection of Escherichia coli $\mathrm{k112}$ with phage $\lambda_{g v}$}

As in the experiments with phage $\lambda_{g c}$, infection was brought about in $0.02 \mathrm{M}$ $\mathrm{MgSO}_{4}$ or in growth medium. When the former procedure was used, the rate of growth of the infected bacteria was less than that of the control bacteria, which grew without lag when resuspended in the tryptone medium (Fig. 6). Phage $\lambda_{g v}$, like phage $\lambda_{g c}$, markedly decreased the synthesis of protein and RNA in the infected 
bacteria. There was no delay in the synthesis of DNA and, even though lysis of the culture began at 30 min., the amount of DNA present continued to increase for about $30 \mathrm{~min}$. at a faster rate than in the control culture, implying that the rate of synthesis in bacteria still unlysed was extremely high (Fig. 6). When infection in the growth medium was studied, and DNA estimated at 5 min. intervals, no lag in the synthesis of DNA was observed and the rate of synthesis was always greater than in the uninfected bacteria.

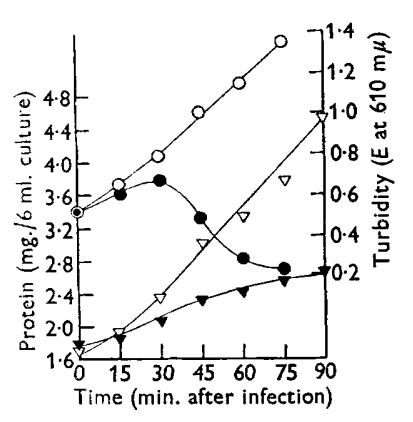

Fig. $5 a$

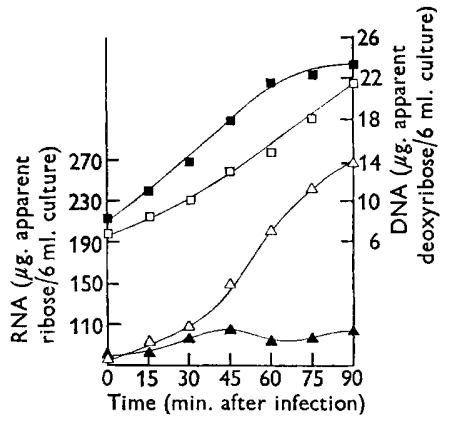

Fig. $5 b$

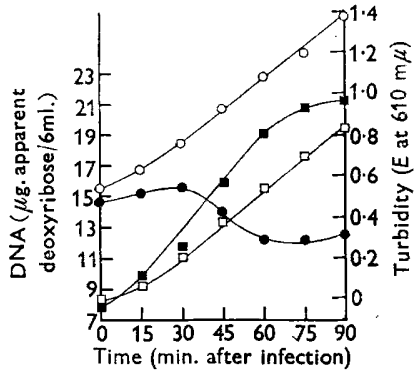

Fig. 6

Fig. 5. Growth of Escherichia coli $\mathrm{K} 112$ and the synthesis of protein RNA and DNA after infection of a growing culture with phage $\lambda_{g c}$. A log-phase culture $\left(5 \cdot 7 \times 10^{8}\right.$ bacteria/ ml.) in TB was divided into two parts. One part received phage $\lambda_{g c}$ plus $\mathrm{MgSO}_{4}$ (final concn. $0.02 \mathrm{M}$ and $8.0 \times 10^{9}$ phage $/ \mathrm{ml}$.) and the other $\mathrm{MgSO}_{4}$ alone. After $15 \mathrm{~min} ., 98 \%$ of the cells were infected. Samples were taken for the estimation of $(a)$ protein $(\nabla, \nabla)$ and turbidity $(O, \odot)$ : and $(b)$ RNA $(\triangle, \Delta)$ and DNA $(\square, \square)$. Closed symbols for infected culture and open symbols for control culture.

Fig. 6. Growth $(O, \odot)$ of Escherichia coli $\mathrm{k} 112$ and the synthesis of DNA $(\square, \square)$ after infection with phage $\lambda_{g v}$ in the presence of $0.02 \mathrm{M}-\mathrm{MgSO}_{4}$ alone. Experimental procedure as for Fig. 4. Initially, $5.0 \times 10^{8}$ bacteria and $1.0 \times 10^{10}$ phage $/ \mathrm{ml}$. in $0.02 \mathrm{M}-\mathrm{MgSO}_{4}: 95 \%$ of the bacteria were infected. Closed symbols for infected culture and open symbols for control culture.

\section{Synthesis of phage-specific proteins}

During the vegetative development of phage new proteins may be formed in the host organism. Some of these are enzymes concerned with the synthesis of specific phage components (e.g. the new DNA polymerase in Escherichia coli infected with phage $\mathrm{T}_{2}$; Aposhian \& Kornberg, 1962), whilst others will be the phage components themselves (e.g. head protein, tail fibres). Specific methods are not yet available for identifying and assaying many of these phage proteins, but two may be studied, namely serum blocking power and endolysin. Serum blocking power (SBP) is the name given to antigenic material in the tail of a phage particle which combines with antibody in phage antiserum and as a result of this combination the phage can no longer adsorb to sensitive bacteria. Endolysin is the name given to a lytic enzyme, similar to lysozyme, which appears in bacteria during the vegetative development of phage and which is regarded as being the same as the lytic enzyme in the tails of mature phage particles.

The time course of the appearance of SBP and endolysin was determined after the induction of $\lambda$ phage development in Escherichia coli $\mathrm{k} 112\left(\lambda_{22}\right)$. Since only small amounts of these materials were to be expected in the early part of the latent period, $100 \mathrm{ml}$. samples of the induced culture were quickly cooled in an ice--salt 
mixture. The bacteria were then collected by centrifugation at $0^{\circ}$, suspended in $10 \mathrm{ml}$. of medium PB, and ultrasonically treated. The same disintegrated suspensions were tested for SBP, endolysin activity and plaque-forming units. The assay for plaque-forming units underestimates the number of mature phage particles present in the bacteria at the time of sampling, since ultrasonic treatment has a lethal effect on some of the phage particles (ultrasonic treatment causes a decrease in the titre of a phage suspension). The experimental procedure was standardized as far as possible, and it was assumed that the proportion of phage which survived would be of the same order in each sample, and that the measured phage titres would reflect changes in the number of mature phage particles in the bacteria.

\section{Table 2. Time course of the appearance of $S B P$, endolysin and phage particles during onset of the induced vegetative development of phage $\lambda$}

An exponential culture of Escherichia coli $\mathbf{K} 112(\lambda)$ was harvested, resuspended, induced and reincubated in the normal way (Methods, p. 416). At time 0 min., $4.5 \times 10^{8}$ bacteria $/ \mathrm{ml} .:$ : $92 \%$ were induced. Samples $(100 \mathrm{ml}$.) were taken at intervals and quickly cooled. The bacteria were collected by centrifugation, suspended in $10 \mathrm{ml}$. PB and then subjected to $5 \mathrm{~min}$. ultra sound. Each disintegrated sample was assayed for SBP, endolysin activity and plaque-forming units. Other samples were taken at intervals to determine turbidity and hence follow residual growth and lysis of induced culture. Temperature during endolysin assay was $22-23^{\circ}$.

Time after
induction
(min.)
0
$\mathbf{1 5}$
20
$\mathbf{2 5}$
$\mathbf{3 0}$
$\mathbf{3 5}$
40

$\begin{array}{cc}\text { SBP } & \begin{array}{c}\text { Endolysin } \\ \text { activity } \\ (\Delta E / \text { min. })\end{array} \\ \text { (phage equivalents/ml.) } & 0.001 \\ 6 \cdot 3 \times 10^{7} & - \\ 6 \cdot 0 \times 10^{7} & 0.001 \\ 6.0 \times 10^{7} & 0 \cdot 03 \\ 5.9 \times 10^{7} & 0.05 \\ 6.6 \times 10^{7} & 0.20 \\ 7 \cdot 6 \times 10^{7} & 0.40 \\ 7.7 \times 10^{7} & \end{array}$

Plaque-forming
units (per ml.)
-
$6.5 \times 10^{5}$
$4.9 \times 10^{5}$
$2 \cdot 4 \times 10^{5}$
$1 \cdot 2 \times 10^{6}$
$3.8 \times 10^{6}$
$3.9 \times 10^{6}$

A small degree of spontaneous induction occurs naturally in a culture of Escherichia coli $(\lambda)$, and it is to be expected that the sample taken immediately after u.v.irradiation would show small amounts of SBP, endolysin and mature phage particles (Table 2). In the experiment reported, endolysin activity began to increase $25 \mathrm{~min}$. after induction, whilst SBP and mature phage showed an increase $30 \mathrm{~min}$. after induction. Since the method for the detection of endolysin is more sensitive than that for SBP, it is not possible to conclude unequivocally that endolysin formation precedes the production of SBP. However, it does seem that the first appearance of these proteins is followed within $5 \mathrm{~min}$. by the formation of the first mature phage particles. In this experiment, lysis began between 52 and 55 min. after incubation of the induced cultures began. In previous experiments (see Fig. 1), lysis normally began at about $60-65 \mathrm{~min}$. The difference was probably due to the time taken to set up the larger amount of culture required in the present experiment. In later experiments the total amount of SBP in the final lysate of an induced culture (105 min. after induction) was as much as 15 times the number of plaque-forming units; that is to say the SBP antigen appears to be produced in great excess as compared with the number of mature phage particles which are eventually assembled. When the phage particles were removed from such a lysate by centrifuga- 
tion at $40,000 \mathrm{~g}$ for $90 \mathrm{~min}$., a large part of the excess SPB remained in the supernatant fluid (Table 3). However, after this first centrifugation, the recovery of phage particles and SPB was only about $50 \%$ of that initially present. In spite of all precautions, and the use of media which contained $0.001 \%$ gelatin and working at $4^{\circ}$, this result was consistently obtained in five experiments. Evidently high-speed centrifugation caused inactivation of some of the SBP and phage particles. Part of the losses of phage particles were probably due to aggregation of particles in the pellet and failure to disperse them completely when resuspended in fresh medium. Kaiser \& Hogness (1960) encountered difficulties in the quantitative recovery of $\lambda$ phage from crude lysates. After the removal of the majority of the phage particles, the amount of SBP in the supernatant fluid was about 18 times greater than the number of phage particles detected by plaque counts. About a quarter of this SBP remained in the supernatant fluid after centrifugation at $96,000 \mathrm{~g}$ for $90 \mathrm{~min}$., whilst about half was found in the pellet. The SBP remaining in the supernatant fluid probably represents molecules of antigenic phage material which was not incorporated into organized structures at the time of lysis of the host bacteria, whilst the SBP in the pellet is probably composed of phage tails and/or fibres; compare the experiments of Franklin (1961) with lysates from E. coli B infected with phage $\mathbf{T}_{2}$.

Table 3. Distribution of serum blocking power and phage particles after differential centrifugation of lysates from induced Escherichia coli ${ }_{\mathrm{K}} 112(\lambda)$

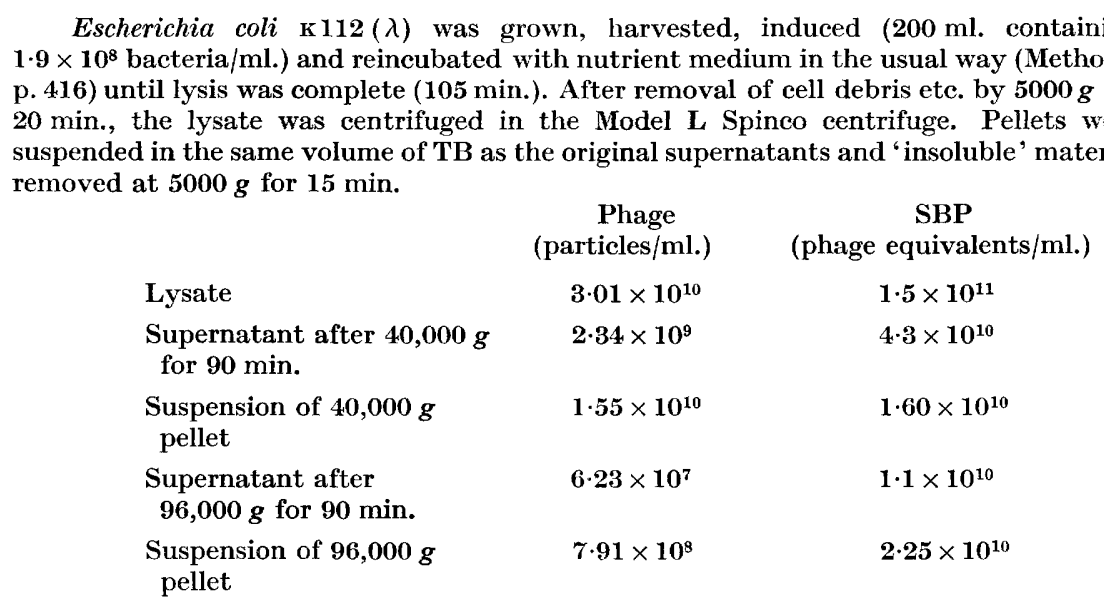

\section{DISCUSSION}

In the experiments reported here, no lag was observed in the synthesis of DNA following infection of Escherichia coli with phage $\lambda_{g c}$ or $\lambda_{g v}$. Moreover, the lag in DNA synthesis in induced bacteria was the same as in bacteria of the non-lysogenic parent strain which had received the same dose of u.v. radiation. This implies that the length of this lag was due to an effect of the irradiation on a process common to lysogenic and non-lysogenic bacteria. These results therefore contrast with those obtained with Bacillus megaterium where, although there was a delay in DNA synthesis after induction of the lysogenic strain, there was no delay after u.v. 
irradiation of the non-lysogenic parent (Siminovitch \& Rapkine, 1952). Séchaud (1960) has studied the effect of infection of $E$. coli with phage $\lambda_{c}$. In her experiments the synthesis of DNA in the bacteria was temporarily inhibited by starvation (incubation in $0.01 \mathrm{M}-\mathrm{MgSO}_{4}$ ) or by starvation and subsequent u.v. irradiation. When such bacteria were returned to a growth medium, there was a lag before DNA synthesis was resumed. This lag was reduced to about $8 \mathrm{~min}$. when the bacteria were infected with phage $\lambda_{c}$ before their return to complete medium. The majority of the adsorbed phage did not inject their DNA into the bacteria until the latter were placed in the growth medium. Injection of the phage DNA took about $4 \mathrm{~min}$. and another $4 \mathrm{~min}$. elapsed before DNA synthesis was resumed. Injection of the phage DNA only when the host organism is in a growth medium appears to be a phenomenon associated with starved bacteria and has not been observed with freshly harvested bacteria. It would therefore seem that the lag in DNA synthesis observed by Séchaud was due to changes brought about by the treatment of the bacteria before infection with phage. We have avoided using starved bacteria, because the primary effects of starvation on cellular metabolism are still unknown and also because starvation by incubation in the absence of sources of nitrogen, carbon and energy profoundly alters the size and composition of the ribonucleoprotein particles of a bacterial cell (Bowen, Dagley \& Sykes, 1959), especially when the starvation medium contains $0.01 \mathrm{M}-\mathrm{MgSO}_{4}$ (Dr J. Sykes, personal communication). Such particles play an important role in the synthesis of protein and perhaps RNA (see McQuillen, 1961). Starvation procedures may also alter the size and integrity of host DNA molecules, and thus diminish or inhibit DNA and RNA synthesis.

Irrespective of whether the development of phage $\lambda$ took place as a result of induction (Fig. 1) or after infection in $\mathrm{MgSO}_{4}$ (Figs. 4a, 6) or in the growth medium (Fig. $5 b$ ), the synthesis of DNA occurred at a greater rate than in the control bacteria. When the amount of DNA estimated to be present in the phage progeny is compared with the net amount of DNA synthesized in the culture (Table 1), it appears that, during vegetative phage development, the synthesis of host DNA is at least very much decreased and perhaps completely inhibited. This is in agreement with the conclusions of Séchaud (1960) from experiments with phage $\lambda_{c}$. Since the bacterial DNA and phage DNA are of identical composition, chemical analysis cannot be used to determine whether only one type or both types of DNA are made during the latent period. If host-cell DNA synthesis is in fact markedly diminished or inhibited during the development of phage $\lambda$, a unique control mechanism would seem to be operating whereby the DNA polymerase is primed for the synthesis of phage DNA, but for some reason the bacterial DNA can no longer act as primer for the synthesis of more host DNA. In phage $\mathrm{T}_{2}$-infected Escherichia coli, the phage initiates the production of enzymes which lead to the removal of one of the substrates (deoxycytidine triphosphate) required for making host DNA (Zimmerman \& Kornberg, 1961). No such mechanism can operate in bacteria infected with phage $\lambda$ since the phage and bacterial DNA are composed of the same four deoxyribonucleotides. It may be suggested that the onset of the vegetative development of phage $\lambda$ causes disorganization or modification of the host DNA such that the latter can no longer act as a primer for the polymerase.

With regard to effects on the synthesis of RNA, the most notable result was seen 
with bacteria which had been infected with phage $\lambda_{g c}$ in the presence of $\mathrm{MgSO}_{4}$ : in such bacteria, net RNA synthesis was completely inhibited (Fig. 4b). Much less extreme effects were observed with induced bacteria (Fig. 2) and bacteria infected in the growth medium with phage $\lambda_{g c}$ (Fig. $5 b$ ) or in $\mathrm{MgSO}_{4}$ with phage $\lambda_{g v}$; in these experiments RNA synthesis was similar to that in the control bacteria for the first third of the latent period and only later became slower so that, at the commencement of lysis, total RNA was somewhat less than half that in the control cultures. The effect of phage development on net protein synthesis was similar to these effects on RNA synthesis, and, for example, became more noticeable in the latter half of the latent period in bacteria infected with phage $\lambda_{g c}$ (Fig. $4 a$ ), where the rate fell to about $30-40 \%$ of that in the control culture.

One of us (W.M.W.) is indebted to the Department of Scientific and Industrial Research for a post-graduate studentship during the course of this work. We gratefully acknowledge a grant from the Rockefeller Foundation, New York, for the purchase of the Spinco centrifuge and the ultrasonic disintegrator.

\section{REFERENCES}

Adams, M. (1950). Methods of study of bacterial viruses. Meth. med. Res. $2,1$.

Aposmina, H. V. \& Kornberg, A. (1962). The polymerase formed after $\mathbf{T}_{2}$ bacteriophage infection of Escherichia coli. J. biol. Chem. 237, 519.

Bessman, M. J. (1960). The enzymology of normal and virus infected Escherichia coli. In The Cell Nucleus. Faraday Soc. Symp. p. 187.

Bowen, T. J., DAgLey, S. \& Sykes, J. (1959). A ribonucleoprotein component of Escherichia coli. Biochem. J. 72, 419.

Burton, K. (1956). A study of the conditions and mechanism of the diphenylamine reaction for the colorimetric estimation of deoxyribonucleic acid. Biochem. J. $62,315$.

Conen, S. S. (1948). The synthesis of bacterial viruses. 1. The synthesis of nucleic acid and protein in Escherichia coli $\mathrm{B}$ infected with $\mathrm{T}_{2} \mathrm{r}^{+}$bacteriophage. J. biol. Chem. 174, 281.

DEMars, R. I. (1955). The production of phage-related materials when phage development is interrupted by proflavine. Virology, $1,83$.

Doerman, A. (1952). Intracellular growth of bacteriophages. 1. Liberation of intracellular bacteriophage $\mathbf{T}_{4}$ by premature lysis with another phage or with cyanide. J. gen. Physiol. 35, 645.

Ellis, E. L. \& Delbruck, M. (1939). 'The growth of bacteriophage. J. gen. Physiol. 22, 365.

Flaks, J. G., Lichtenstein, J. \& Cohen, S. S. (1959). Virus induced acquisition of metabolic function. II. Studies on the origin of the deoxycytidylate hydroxymethylase of bacteriophage-infected Escherichia coli. J. biol. Chem. 234, 1507.

Franklin, N. C. (1961). Serological study of tail structure and function in coliphages $\mathrm{T}_{2}$ and $\mathrm{T}_{4}$. Virology, 14, 417 .

Fry, B. A. (1959). Conditions for the infection of Escherichia coli with lambda phage and for the establishment of lysogeny. J. gen. Microbiol. $21,685$.

Hershey, A. D. (1953). Nucleic acid economy in bacteria infected with bacteriophage $\mathbf{T}_{2}$. II. Phage precursor nucleic acid. J. gen. Physiol. 37, 1.

Hershey, A. D. \& Burgi, E. (1956). Genetic significance of the transfer of nucleic acid from parental to offspring phage. Cold Spr. Harb. Symp. quant. Biol. 21, 91.

JACOB, F. \& Fuerst, C. R. (1958). The mechanism of lysis of phage studied with defective lysogenic bacteria. J. gen. Microbiol. 18, 518.

Jacob, F. \& Wollman, E. L. (1954). Étude génétique d'un bactériophage tempéré d'Escherichia coli. 1. Le système génétique du bactériophage $\lambda$. Ann. Inst. Pasteur, 87, 653. 
J ACOB, F. \& Woldman, E. L. (1956a). Recherches sur les bactéries lysogènes défectives. 1. Déterminisme génétique de la morphogénèse chez un bactériophage tempéré. Ann. Inst. Pasteur, 90, 282.

JACOB, F. \& Wollman, E. L. (1956b). Sur les processus de conjugaison et de recombinaison chez Escherichia coli. 1. L'induction par conjugaison ou induction zygotique. Ann. Inst. Pasteur, 91, 486.

Kaiser, A. D. \& Hogness, D. S. (1960). The transformation of Escherichia coli with desoxyribonucleic acid isolated from bacteriophage $\lambda_{d g}$. J. molec. Biol. $2,392$.

Kelner, A. (1953). Growth, respiration and nucleic acid synthesis in ultraviolet-irradiated and in photoreactivated Escherichia coli. J. Bact. 65, 252.

Lowry, O. H., Rosebrough, N. J., Farr, A. L. \& Randall, R. J. (1951). Protein measurement with the Folin reagent. J. biol. Chem. 193, 265.

LwoFf, A. (1953). Lysogeny. Bact. Rev. 17, 269.

McQuillen, K. (1961). Ribosomes and the synthesis of proteins. Progr. biophys. Chem. 12, 67.

Schneider, W. C. (1945). Phosphorus compounds in animal tissues. 1. Extraction and estimation of deoxypentose nucleic acid and of pentose nucleic acid. J. biol. Chem. 161, 293.

SÉchaud, J. (1960). Développement intracellulaire du coliphage lambda. Arch. Sci. phys. nat., Génève, 13, 428.

Siminovitch, L. \& Rapkine, S. (1952). Biochemical modifications in lysogenic Bacillus megaterium 899 (1) after induction with ultra violet light. Biochim. biophys. Acta, 9, 478.

Weigle, J. J. \& Delbruck, M. (1951). Mutual exclusion between an infecting phage and a carried phage. J. Bact. 62, 301.

Zimmerman, S. B. \& Kornberg, A. (1961). Deoxycytidine di- and tri-phosphate cleavage by an enzyme found in bacteriophage infected Escherichia coli. J. biol. Chem. 236, 1480. 